\author{
Anetta Bogusława STRAWIŃSKA \\ Uniwersytet w Białymstoku \\ anetta.strawinska@tlen.pl
}

\title{
GLAMOUR - MAGIC OR MANIPULATION? A SHORT HISTORY AND DEFINITION ${ }^{1}$
}

In modern informal Polish ${ }^{2}$ the lexeme glamour has become almost as common as Aglicisms such as super, ekstra or $\mathrm{cool}^{3}$. The increasing popularity of the universalism ${ }^{4}$ is strengthened by the influence of a popular women's magazine with this title ${ }^{5}$, as well as the almost unbelievable

1 The synthetic character of the text results from the editorial requirements of this work. The article is a shorter version of a presentation I delivered on $17^{\text {th }}$ April 2013 at a conference in Rzeszów. The title of the conference was Obszary polonistyki. Język literatura - kultura.

2 The term informal Polish is used here in the meaning of a form of Polish which is "most frequently used, by the greatest number of people, in various situations of daily life and which consists primarily of the most basic forms and meanings, establishing the basic structures of thinking and perception of the world connected to the basic human needs is basic existential situations" ["używana najczęściej, przez największą liczbę osób, w najróżniejszych sytuacjach życiowych, zawierająca przede wszystkim zasób podstawowych form i sensów, utrwalająca elementarne struktury myślenia i percepcji świata związane z elementarnymi potrzebami człowieka w elementarnych sytuacjach egzystencjalnych" Bartmiński 2008: 116].

3 This hypothesis is confirmed by information I gathered based on interviews conducted in 2011-2013 among students of Polish Philology, Cultural Studies ( $1^{\text {st }}$ year) and Library and Information Science ( $1^{\text {st }}$ and $2^{\text {nd }}$ year) at the University of Białystok, who described the word as "frequently or increasingly frequently used, popular, common and fashionable in the language of 20-year-olds". Modern normative sources do not include this word.

4 The noun glamour entered the world's languages in its English form and is universally recognized. It is undoubtedly one of the so called internationalisms, or "words belonging to the common vocabulary of various languages" ["wyrazów należących do wspólnego słownictwa różnych języków" [Pisarek 1992: 127], or "of international use" ["mających międzynarodowy zasięg" por. Maćkiewicz 2008: 556-559].

5 "Glamour" is an international monthly magazine for women, published in Poland (by Gruner + Jahr Polska) since April 2003. A popular actress Joanna Brodzik took part in 
impact of gossip portals ${ }^{6}$, which make use of this lexeme as a key-word for describing various socio-cultural phenomena. In internet portals the word glamour is used mainly in relation to movie stars (such as Marlena Dietrich, Ava Gardner, Sophia Loren, Elizabeth Taylor or Marilyn Monroe) or fictional cultural icons (James Bond, Barbie doll). The analysed word is used first of all as a synonym for someone who is charming, physically attractive, alluring, sexy. The lexeme glamour is often used to describe enchanting architecture (budynek glamour - a glamour building) and baroque interior design (komoda glamour, stót glamour, krzesło glamour - a glamour chest, table, chair). The word is also frequently used to describe astounding fashion (kolekcja glamour - a glamour collection), luxurious cars (marka glamour - a glamour brand), or even intriguing gadgets (tablet glamour, pasek glamour, etui glamour - a glamour tablet, belt, etui). Such broad usage context gives rise to the seemingly naive question: What is the meaning of the phrase (or more accurately concept) glamour?

The largest Polish-English on-line dictionary ${ }^{7}$ (through references to other dictionaries such as: PARK, EXETER, ECTACO, Word Net Stownik, Webster Dictionary of English) defines glamour as 'blask' (shine), 'czar' (charm), 'magię' (magic), 'piękno' (beauty), 'bycie pociągającym (atrakcyjnym fizycznie)' (physical attractiveness), 'przepych' (luxury), 'splendor' (splendour), 'świetność' (excellence), 'urok (uniemożliwiający prawidłową percepcję)' (bewitchment - inhibiting perception), 'wspaniałość czy zaklęcie (kogoś lub czegoś)' (magnificence or enchantment (of someone or something)), 'rodzaj mgły w powietrzu powodującej, że rzeczy są inne niż w rzeczywistości' (a kind of mist in the air, which causes things to be different from reality), 'wszelkie sztuczne zainteresowanie, tzn. związek z obiektami, przez

its promotional campaign. Since 2007 "Glamour", has been granting awards for "Woman of the Year", "Creativity in Business", "Glamour Entrance", "Show Business", "Foreign Celebrity". The magazine is divided into the following parts: "Planet Glamour", fashion, health and beauty, life and happiness, men, sex and love, opinion column, culture and new publications (books, music, interview of the month). There is also a social media portal "Club Glamour", http://www. glamour.pl, date of access: 06.02.2013.

6 The number of search results including the word glamour, as of $27^{\text {th }}$ August 2012, based on data from internet portals: Efakt.pl - 25.300, Kobieta.pl - 23.300, Wieszjak.pl - 1.290, Egoiści.pl (wrzuta.pl video) - 1.117, Koktajl.pl - 831, Lula.pl - 661, Plotek.pl - 591, Mtv.pl - 570, Polki.pl - 330, Plejada.pl - 115, Kozaczek.pl - 96, Kotek.pl - 65, Lansik.pl - 52, Zeberka.pl - 36, Topstars.pl - 35, Pomponik.pl - 27, Lux-lux.pl and No co ty.pl - 16, Superexpress.pl (se.pl) - 13, Onet.pl. muzyka-plotki - 8, W-spodnicy.pl-7, Obmawiamy.pl and Pudelek.pl -6 .

7 Ling.pl, http://www.ling.pl/glamour, data of access: 08.01.2013. 
które wydaje się, że ktoś (lub coś) staje się do kogoś (czegoś) łudząco podobnym, także fałszywie uwielbianym' (any fake interest, i.e. connection to objects, which causes somebody (or something) to be deceptively similar to somebody (something), also falsely).

The Anglicism glamour has its own history. In literature it was used for the first time by the romantic Scottish poet and novelist sir Walter Scott ${ }^{8}$, in The Lay of the Last Minstrel [1805] ${ }^{9}$, includes the tale of a dwarf who uses the powers of gramarye "magic" to turn into a superhumanly beautiful and strong trickster ${ }^{10}$. According to Scott, both the experience of glamour and the word itself are inseparably connected to the supernatural, occult and magical practices which can revert spells. This is confirmed in the ballad Christie's Will [Scott 1825], which includes the phrase glamour'd gang used to describe a group of Gipsies, which uses the power of a spell to ruthlessly trick a certain teacher ${ }^{11}$.

Carol Dyhouse's research confirms that prior to 1900 the meaning of glamour was ambiguous. It meant an illusionary charm, a dangerous spell, a magical enchantment and was usually used in reference to magic and the occult. It is important from my perspective that $C$. Dyhouse also indicates that the meaning of this lexeme was extended in the Victorian

8 Scott is a representative of regionalism in $19^{\text {th }}$ century British literature. Similarly to other authors of so called regional novels, he concentrated on the life of the community living in a given land, as well as its traditions and local flavour [Gazda 2009: 612].

9 IX: "And one short spell therein he read./ It had much of glamour might,/ Could make a ladye seem a knight;/ The cobwebs on a dungeon wall,/ Seem tapestry in lordly hall;/ A nut-shell seem a gilded barge,/ A sheeling seem a palace large,/ And youth seem age, and age seem youth-/ All was delusion, nought was truth" [...]; XI: He took him to Lord David's tower,/ Even to the Ladye's secret bower;/ And, but that stronger spells were spread,/ And the door might not be opened,/ He had laid him on her very bed./ Whate'er he did of gramarye,/ Was always done maliciously./ He flung the warrior on the ground", http://scott-minstrel.cath.vt.edu/documents.php?select=Jeffrey, date of access: 20.01.2013.

10 In a thesaurus accompanying the poem Scott also provides his own definitions: glamour is 'magical delusion', in contrast to gramarye - 'magic' and gramercy - 'Thank you, from the French Grand merci'. In his explanations to the $3^{\text {rd }}$ part of the poem, he adds: "The art of glamour, or ocular fascination, was anciently a principal part of the skill of the jongleur, or juggler, whose tricks formed much of the amusement of a Gothic castle. Some instances of this art may be found in the Minstrelsy of the Scottish Border [...]. In a strange allegorical poem, called the Houlat, written by a dependant of the house of Douglas about 1452-3, the jay, in an assembly of birds, plays the part of the juggler" [Scott 1805: 250-253].

11 "He thought the warlocks o' the rosy cross/ Had fang'd him in their nets sae fast;/ Or that the gypsies' glamour'd gang", http://literaryballadarchive.com/PDF/Scott_6_Christie_s_Will_f. pdf, date of access: 12.12.2012. 
era, by adding to it a pejorative element ${ }^{12}$, as the word glamour is always accompanied by a warning. [2010: 9] ${ }^{13}$.

The thesis that the word glamour, as used since the $19^{\text {th }}$ century, is irrevocably connected to "dangerous magical transformation and change" is also presented by Judith Brown [2009: 9-10]. In her work Glamour in Six Dimensions she stresses that this enchantment has been given its particular meaning by modernist authors, who would, for example, invoke an image of a fear-inducing "luminous halo"14 (Virginia Woolf).

The connection this lexeme has with magic, spells, enchantment, illusion and mirage is confirmed by the Revised Unabridged Webster's Dictionary [1913] ${ }^{15}$, which indicates that "glamour was a literal magic spell. Not a metaphorical one the way we use it today, but a literal magic spell, associated with witches and gypsies and, to some extent, Celtic magic"16. The origin of the word glamour can most likely be found in the Scottish gramarye "magic, spell"17. The Oxford English Dictionary states that

$12 \mathrm{H}$. Rybicka-Nowacka characterises a number of directions of semantic change. These include: narrowing of the use of a borrowed word (in comparison with the source language), extending the use of the word in the receiving language, changes in the emotional flavour of a word [1976: 106-117].

13 This hypothesis is confirmed for example by the poem: A Victim to Glamour by Williama Berry (1874), which depicts the fate of Annie, a miller's servant, who ignores the feelings of the smith, who is madly in love with her, and decides to seduce the ugly son of her rich employer. She is successful in her thoughtless and naive designs, which leads to a duel between the two lovers. A stray bullet nearly kills her. Her long and painful convalescence eventually leads to the "breaking of the veil", which prevented her from seeing the world clearly and assessing the reality and people correctly. Consequently, Annie decides to "give her heart" to the poor, but good, Walter, http://www.forum.iranproud.com/attachment.php?attachmentid=157004, date of access: 07.01.2013.

14 "A halo (from Greek $\alpha \lambda \omega \varsigma$, hal-os;[1] also known as a nimbus, icebow or gloriole) is an optical phenomenon produced by ice crystals creating colored or white arcs and spots in the sky. Many are near the sun or moon but others are elsewhere and even in the opposite part of the sky. They can also form around artificial lights in very cold weather when ice crystals called diamond dust are floating in the nearby air.", Wikipedia https://en.wikipedia.org/wiki/Halo_(optical_phenomenon), date of access 25.02.2014.

15 See $1^{\text {st }}$ ed. http://dictionary.die.net/glamour, date of access 26.03.2013.

16 See: V. Postrel, On Glamour - a TED talk presented in Monterey (California) in February 2004, http://www.ted.com/talks/virginia_postrel_on_glamour.html, date of access: 03.12.2012.

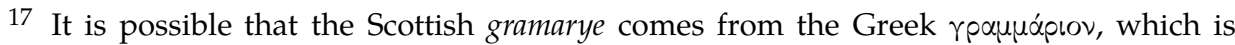
"the weight unit of ingredients used to make magic potions" http://en.wiktionary.org/ wiki/glamour, date of access: 07.02.2013. Its meaning is similar the French grimoire '1. A book of magic, 2. Illegible writing', which also takes on the form grymuar - a book of magic, often including astrology, spells, lists of angels and demons, etc. [Mathers, Crowley 2000: 11]. 
the Word glamour, originally used by Scots and traditionally connected to beauty and charm or unusual attractiveness, comes from the same source as the borrowing from Greek grammatic ( $\left.ү \rho \alpha \mu \mu \alpha \tau i x \eta^{\prime}\right)^{18}$, which means 'learning, more precisely: occult practices"19. This is further confirmed in New Fowler's Modern English. Fowler's dictionary states that etymologically glamour ("occult, learning, magic, necromancy") comes from grammar ${ }^{20}$.

For many years establishing the origins of the word glamour was problematic ${ }^{21}$. This confusion was finally settled by the English linguist Richard Hudson, who confirmed, after years of meticulous analysis of all available sources, the Latin origin of the lexeme ${ }^{22}$.

The word glamour is therefore an indirect borrowing ${ }^{23}$ of primary Greco-Roman provenience, brought into Polish through English.

As glamour is decidedly outside the bounds of any one style, forming a single unambiguous definition of the experience is - in my opinion - im-

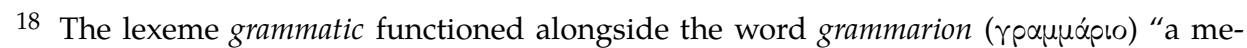
dieval measure of weight; gram", http:/ewongowordpress.com/2009/12/27/etymologyof-glamour, date of access: 18.02.2013.

19 In the middle ages occult knowledge was considered a science. This is not grammar in the literal sense (from Latin grammatical "a set of rules governing language"). According to dictionaries the semantic shift took place at the start of the $18^{\text {th }}$ century, http://oxforddictionaries.com/definition/english/glamour, date of acces: 06.11.2012.

20 This concept is supported by Anatoly Liberman. In his opinion the original source of the word glamour is the Greek noun for a "letter", http://www.in.com/anatolyliberman/biography-18147.html, date of access: 24.01.2013. Furthermore, Liberman found that in the $13^{\text {th }}$ century French, an "evil twin" was born to the word gramaire "grammar" - grimoire. Originally this lexeme referred to latin grammar only in the meaning of "something illegible" (an allusion to the French grimaud "bleak, gloomy"). Soon it came into use in two meanings: "a book for occult learning, a book of magical spells" and "gibberish". Liberman suggests that the French grimoire was adopted into English in the $14^{\text {th }}$ century as gramaire, while sir Walter Scott revived its original medieval "magical" sense [2005: 36-37].

21 It has been falsely attributed to old Icelandic glamr "one of the names for the Moon" equivalent to English gloam and Icelandic glamsyni "illusion", http://books.google.pl/ books?id=sMiRcJFIfMC\&pg=PA319\&lpg=PA319\&dq=Word+Origins+And+How+We+ Know+Them:+Etymology+for+Everyone+str+37\&source=bl\&ots=XLe8EDc_GD\&sig= V4PTODen0HN3rGKhl3Ka_cE7oMs\&hl=pl\&sa=X\&ei=EM1yUO2JLYvSsgaErYBw\&ved= 0CCwQ6AEwAQ\#v=onepage\&q=Word \%20Origins $\% 20 \mathrm{And} \% 20 \mathrm{How} \% 20 \mathrm{We} \% 20 \mathrm{Know}$ $\% 20$ Them $\% 3 \mathrm{~A} \% 20$ Etymology $\% 20$ for $\% 20$ Everyone $\% 20$ str $\% 2037 \& \mathrm{f}=$ false date of access: 20.12.2012.

22 Glamour = lat. grammatica "an organised collection of rules describing the system of a language". Sum: Grammar and glamour LINGUIST List 6.1197 Fri Sep 11995 http://linguislist.org/issues/6/6-1197.html, date of access: 13.12.2012. [See also Dubisz 2003: 1068].

23 I am using the traditional typology according to Rybicka-Nowacka [1976: 37-54]. 
possible. Regardless of its historical, political, social and cultural context, glamour takes on many forms ${ }^{24}$. It is a unique and original phenomenon.

Therefore, my main objective is not so much to define glamour, but to unmask the fraudulence of the process. Glamour is a deliberate mystification ${ }^{25}$, with the aim of creating interest in a particular movie or TV star; an almost universal desire for luxury goods or services. Glamour does not necessarily refer to people. Someone or something (a particular, exclusive creation of modern industry) ${ }^{26}$ that is glamour must first of all be "transcendent" - i.e. have the ability to transcend the borders of this world and reach the unreachable, the perfect and the otherworldly ${ }^{27}$.

According to Virginia Postrel, it is socio-culturally natural to "have ideals that cannot possibly be realized in reality. (...) And in the life of an individual, we often associate that with some object. (...) The perfect love life - symbolized by the perfect necklace, the perfect diamond ring. The perfect getaway in your perfect car. (...) We want this golden world. And some people get rich enough, and if they have their ideals - in a sort of domestic sense, they get to acquire their perfect world." [2004].

This beautiful reality of beautiful people created by the media (not in the sense of becoming beautiful through an arduous process and hard work, but as the final product: being merely beautiful on the outside) is a fiction. This is probably why those who study this phenomenon, regardless of the specialty or school of thought they represent, underline its theatricality. In my opinion glamour is an artificial representation of beauty. However, it is honest about it ${ }^{28}$. This trick leads us to believe that our dull, monotonous life may become better. While we, flawed,

24 There is a number of types/versions of glamour. E.g. the glamour of garage entrepreneurs, architecture, politics, industry, space, or Tibetan glamour.

25 Glamour invites us to an illusionary space; an alien, semi-transparent world, which has to be at once mysterious and distant.

26 Glamour refers to all areas of life. It is a synonym for all high quality things.

27 For example, the spiral staircase created by Morris Lapidus in hotel Fontainebleau is glamour [Friedman 2005: 243]; they feel both ascendant and semi-transparent [Postrel 2004].

28 According to Postrel, to achieve glamour one needs to use the Renaissance art of sprezzatura, or "the art that conceals art". Thus, achieving glamour requires the skill of keeping details secret, which prevents the created image from representing the actual reality as it is [2004]. The term sprezzatura was coined by Castiglionego in Il Cortegiano, and borrowed into Polish by Łukasz Górnicki in Dworzanin Polski, in the forms of the abbreviations "niedbałość abo nizaczmienie", which refer to a certain freedom of behaviour and nonchalance, which hide artificiality [Sinielnikoff 1962: 6;11]. 
mediocre, humdrum, are capable of becoming a part of a perfect world ${ }^{29}$. Thus glamour is a "pure aspiration"; it is a "great promise", a kind of dream, which may come true. Glamour, as fictional attractiveness, should be seen through the lens of the empirical needs of consumers, sexuality and fantasy [Brown 2009: 1] ${ }^{30}$. Therefore, glamour is identified less with an alternative reality and more with possibilities, the state of permanent enchantment with the ever newer versions of its temptation. It is less philosophical and more speculative. It is merely a suggestion of potential possibilities to be realised ${ }^{31}$. After all, any glamorous ${ }^{32}$ man or woman is capable of creating their own seductive image in any way they like [Gundle 2011] ${ }^{33}$.

According to Gundle, who describes glamour in the context of modern consumption culture, this universal yearning after a better, more attractive and exciting life (and increased consumption), had a natural ability to evoke fantasy in people [2008: 20] ${ }^{34}$. In his opinion, visual factors, especially architecture, played a major role in the birth of glamour, as a prestigious lifestyle. This hypothesis is supported by Alice Friedman ${ }^{35}$ (author of American Glamour and the Evolution of Modern Architecture) -

29 Just like movie stars, celebrities, top politicians, and the modern 'rags to riches' icons (those who thanks to their talents, determination and conscientiousness achieved success in the form of fame, adoration and wealth). They are the most effective vectors of glamour. Gundle describes their actions as a powerful story about those who started with nothing and achieved a lot; who support the key promise of change [2008: 380].

30 Glamour tempted (and still does) with the idea that anything and anyone can change. The world may be better, people more attractive and wealth actually attainable.

31 This explains why the experience of glamour appears as a complete vision. It lasts until it is replaced by a newer version of the spell. No single act of magic can hold our attention for long, as any longer series will finally dispel it.

32 This is the lexeme used by Gundle on Facebook.

33 See GLAM ROKS - Adapted by Claire Coleman from Glamour: A History by Stephen Gundle. 10 July 2011, http://www.facebook.com/notes/hollywood-golden-era-screen-sire ns/glam-rocks-adapted-by-claire-coleman-from-glamour-a-history-by-stephen-gundl/101 50254750552768, date of access: 06.02.2013.

34 According to Gundle, the concept of glamour is irrevocably connected to political changes in Europe and beyond - the transition from an aristocratic to a bourgeois society. The flashy style of glamour developed alongside the revolution of freedom and equality. Regular people started to perceive themselves as an integral part of a society which includes them as well as the rich and famous www.goodreads.com/book/show/4600506glamour, date of access: 04.02.2013.

35 A. T. Friedman is a professor of American art history at Wellesley College. Her research and teaching focus on modern architecture and history of design in USA. Her research interests include: gender issues, cultural studies, social history, http://new.wel lesley.edu/art/faculty/friedman, date of acces: 03.03.2013. 
who believes that designers from the late 1940s and 1950s responded to the needs of American clients generated by advertising and modern media by breaking with cultural and aesthetic stereotypes and creating surprising visions ${ }^{36}$ of perfect, theatrical, futuristic architecture (e.g. corporate HQs, hotels, villas, churches) ${ }^{37}$ [Friedman 2010: 4-5; see also Isenstadt $^{38}$ 2011].

At the beginning of the $20^{\text {th }}$ century window displays, posters and mass events opened the world of glamour in its stable version. Modern media (cinema, television, Internet) have no qualms about promoting luxury and elegance. This makes the society more open and through glamour more visible.

However, glamour should not be analysed only as a superficial phenomenon (this unauthentic beauty), because besides that it also includes the charisma and magnetism of particular people commonly considered stars. It draws people closer to the world of celebrities ${ }^{39}$. Being glamour is therefore not dependant on looks but on style and self-confidence. It requires self-development (although not conspicuous), overcoming one's shortcomings and fears, to become better, perfected even. It is possible, but never easy [Gundle 2008: 380] ${ }^{40}$.

Because of its unpredictability glamour undoubtedly belongs to the category of dangerous phenomena ${ }^{41}$. One cannot underestimate the

36 The trick was to combine well known and socially accepted solutions with innovative and shocking new trends in modern architecture.

37 She sees glamour as a substitute for something magical, luxurious and exceptional, invoking such examples of glamour in architecture as: the TWA terminal in New York designed by Saarinen, the Four Seasons restaurant in New York - by Johnson, the Seagram corporate headquarters in Montreal - by Mies van der Rohe , or Elvis Presley's Gracelnd mansion in Memphis Tennessee [2011].

38 S. Isenstadt - professor and director at the Faculty of History of Modern Architecture at Delaware University. In his article The Modern House American, he describes the visual accessories of spaciousness in architectural design, particularly American interior and landscape design, http://www.udel.edu/ArtHistory/faculty/isenstadt.html, date of access: 13.12.2012.

39 Even though this is a restricted space, available only to a few (or to the privileged), it is tempting and alluring. It forces people to get involved (often to the point of obsession) and to take risks to shine like a show-business star.

40 Although we could potentially become celebrities, in actual fact most of us will not be able to achieve this. In result we are fascinated with those who (although they come from a background similar to ours) belong to a different (in our opinion better) world.

41 That glamour can be dangerous, we learned in early $20^{\text {th }}$ century, when it was ruthlessly used fascist and communist theorists. National socialism was, according to Postrel, "was a very aesthetic ideology. It was all about cleaning up Germany, and the West, and the 
power of enchantment and people who have these qualities. In the past, when a magical spell was cast, it was rarely with good intent. On the contrary, the goal of most witches was to force the victim to herself act (against her will) against her own interest.

Nowadays we are systematically and ruthlessly subjected to enchantment - intellectual and aesthetic mind control ${ }^{42}$. This purpose is served by a huge technical effort consisting of the cosmetics, fashion, automobile, building, TV and movie industry.

In the words of Zygmunt Bauman, it is a sign of our times that "culture is now made up of offers, rather than orders; of propositions, rather than norms; [...] it works through lures and baits, temptation and seduction rather than normative regulations [...] production, dissemination and planting of new needs, desires, and dreams" [2011: 27].

In the modern consumer society culture is "a collection of wares designed for consumption, each of which competes for the unbearably fleeting and diffuse attention of clients in the hope of keeping it for more than the blink of an eye" [Bauman 2011: 28] ${ }^{43}$.

\section{LITERATURE}

Bartmiński J., 2008, Styl potoczny, [w:] Wspótczesny język polski, red. J. Bartmiński, Lublin, s. 116-134.

Bauman Z., 2011, Kultura w płynnej nowoczesności, Warszawa.

world, and ridding it of anything unglamorous." [2004]. Brown also notices the dangers of glamour indicating that in 1930 glamour became an accessory to fascism, which used the power of glamour imagery and engineering drawing people in like a vortex, mainly thanks to Hitler's apologist Leni Riefenstahl (a German film director, who was as controversial as her work) [2009: 17].

42 Popular culture (or the culture of average people, those who feel the same as others; who have common goals, ideas or lifestyles), which "crushes beneath it everything that is different, everything that is excellent, individual, qualified and select." [Ortega y Gasset 1993: 495-498]. It takes away clarity of thinking, it makes us fall victim to the illusion of a beautiful, easy life, almost constantly forced upon us by television, Internet, billboards and tabloids. Teams of marketing specialists work daily on new strategies to make us silently accept the reality of the media-created life based on pleasures; a world with no worries and problems; the existence of the crafted superhumanly beautiful, rich, happy people, who can achieve anything without effort.

43 "Disposing of inflexible standards, indiscrimination, accepting any tastes with no preference and no direct commitment to any one of them, "elasticity" of preference, as well as temporariness and inconsistency of choices are the characteristics of the strategy put forward today as the only reasonable and appropriate. Today maximal tolerance and minimal discrimination are the signs of belonging to a cultural elite" [Bauman 2011: 28]. 
Brown J. C., 2009, Glamour in Six Dimensions: Modernism and the Radiance of Form, London.

Dubisz S., 2003, Uniwersalny słownik języka polskiego, Warszawa.

Dubisz S., Sobol E., 2007, Wielki słownik frazeologiczny, Warszawa.

Friedman A. T., 2005, Merchandising Miami Beach: Morris Lapidus and the Architecture of Abundance, "The Journal of Decorative and Propaganda Arts", vol. 25, The American Hotel, s. 216-253.

Friedman A. T., 2010, American Glamour and the Evolution of Modern Architecture, Yale.

Gazda G., 2009, Słownik europejskich kierunków i grup literackich XX wieku, Warszawa.

Gundle S., 2008, Glamour: A History, Oxford.

Isenstadt S., 2011, American Glamour and the Evolution of Modern Architecture, Jan 20, Designobserver.

Liberman A., 2005, Word Origins - and How We Know Them: Etymology for Everyone, Oxford.

Maćkiewicz J., 2008, Wyrazy międzynarodowe (internacjonalizmy) we wspótczesnym języku polskim, [w:] Wspótczesny język polski, red. J. Bartmiński, Lublin, s. 554-562.

Mathers M., Crowley A., 2000, GEOCJA wg Aleistera Crowley'a, Wrocław.

Ortega y Gasset J., 1993, Bunt mas, [w:] Wiedza o kulturze, cz. 1: Wprowadzenie do wiedzy o kulturze. Zagadnienia i wybór tekstów, oprac. G. Godlewski, L. Kolankiewicz, A. Mencwel, M. Pęczak, Warszawa, s. 493-507.

Rybicka-Nowacka H., 1976, Losy wyrazów obcych w języku polskim, Warszawa.

W. Scott, 1830, Listy o demonologii i czarach, Londyn.

Scott W., 1805, The Lay of the Last Minstrel: a Poem, London.

Sinielnikoff R., 1962, Z badań nad kultura językowa XVI wieku. Nazwy pojęć w "Dworzaninie" Górnickiego, "Poradnik Językowy", z. 1, s. 1-12.

\section{GLAMOUR - MAGIC OR MANIPULATION? A SHORT HISTORY AND DEFINITION}

\section{Summary}

The article is an attempt to systematise the definition of glamour and establish the etymology of the word. The author analyses glamour through extra-linguistic factors, i.e. in the context of political, cultural and social change not only in Poland, but throughout Europe and the world.

It is the main intention of the author to unmask the fraud carried by glamour. Glamour is a deliberate mystification, with the aim of arousing interest in a particular movie or TV star; the almost universal desire for luxury goods 
and services. These needs are served by a huge technical effort in the form the cosmetic, fashion, automobile, movie and TV industry. This fraud was and is possible because the desire for luxury and showing off is part of human nature.

Key words: changes in modern Polish, mystification, linguistic fashion, falshood in language

\section{GLAMOUR - MAGIA CZY MISTYFIKACJA? HISTORIA I DEFINICJA ZJAWISKA W ZARYSIE}

\section{Streszczenie}

Artykuł jest próbą usystematyzowania definicji leksemu glamour oraz ustalenia etymologii omawianego zjawiska. Autorka tekstu, glamour analizuje przez pryzmat czynników zewnątrzjęzykowych, tzn. w kontekście przemian politycznych, kulturowych, obyczajowych oraz społecznych obejmujących swym zasięgiem nie tylko Polskę, ale przede wszystkim Europę i świat.

Intencją autorki tekstu jest przede wszystkim demaskacja fałszerstwa, jakie analizowany proces ze sobą niesie. Glamour jest bowiem przemyślaną mistyfikacją, której celem jest wzbudzenie zainteresowania konkretną gwiazdą filmową czy telewizyjną; niemal powszechnego pożądania luksusowych produktów i usług. Tym potrzebom podporządkowany jest ogromny nakład techniczny w postaci m.in. przemysłu kosmetycznego, modowego, samochodowego, budowlanego, filmowego i telewizyjnego. To fałszerstwo było i jest możliwe dlatego, że w ludzkiej naturze mieści się dążenie do luksusu oraz szokowanie innych.

Słowa kluczowe: przemiany współczesnej polszczyzny, mistyfikacja, moda w języku, fałsz w języku 